\title{
PENGARUH PENAMBAHAN MALTODEKSTRIN DAN PUTIH TELUR TERHADAP KARAKTERISTIK BUBUK KALDU JAMUR TIRAM
}

\section{The Effect of Maltodextrin and Egg White on Characteristic of White Oyster Mushroom Broth Powder}

\author{
Ahmad Faruq Abidin ${ }^{1}$, Sudarminto Setyo Yuwono ${ }^{1}$, Jaya Mahar Maligan,2* \\ 1) Jurusan Teknologi Hasil Pertanian, FTP Universitas Brawijaya Malang \\ 2) Pusat Studi Pengembangan Pangan Lokal, Universitas Brawijaya \\ Jl. Veteran, Malang 65145 \\ *Penulis Korespondensi: Email: maharajay@gmail.com
}

\begin{abstract}
ABSTRAK
Tujuan penelitian ini adalah untuk mengetahui pengaruh serta interaksi penambahan putih telur dan konsentrasi penambahan maltodekstrin terhadap karakteristik organoleptik, fisik dan kimia bubuk kaldu jamur tiram putih yang dihasilkan menggunakan metode foam mat drying. Rancangan percobaan yang digunakan pada penelitian ini adalah Rancangan Acak Kelompok (RAK) dengan 2 faktor, dimana faktor I adalah konsentrasi maltodekstrin (10\%, 15\% dan $20 \%$ ) dan faktor II adalah konsentrasi putih telur (10\%,15\% dan $20 \%)$. Data dianalisis menggunakan ANOVA dan dilanjutkan dengan uji DMRT. Hasil penelitian menunjukkan konsentrasi maltodekstrin dan konsentrasi putih telur memberikan pengaruh terhadap karakteristik fisikokimia dan organoleptik dari bubuk yang dihasilkan. Berdasarkan organoleptik, perlakuan terbaik adalah penambahan maltodekstrin $10 \%$ dan putih telur $20 \%$. Perlakuan terbaik memiliki karakteristik warna $L^{*}, a^{*}$, $b^{*}$ sebesar $76.9 ; 9.35 ; 18.44$, Densitas busa sebesar $0.20 \mathrm{~g} / \mathrm{mL}$, rendemen $29.10 \%$, daya larut $96.41 \%$, kadar air sebesar $6.58 \%$, kadar protein sebesar $5.77 \%$.
\end{abstract}

Kata Kunci: Bubuk Kaldu, Foam mat drying, Jamur, Maltodekstrin, Putih telur

\section{ABSTRACT}

The pupose of this study is to determine the effect of various maltodextrin and egg white concentration on the organoleptics, physical and chemical characteristics of mushroom broth powder. This study used Factorial Randomized Block Design with two factors. The first factor is maltodextrin concentration (10, 15 and 20\%), while second factor is egg white concentration (10,15 and 20\%). Then the characteristics properties were analyzed using ANOVA (95\%). When there were significant differences in the interaction between two factors, further testing is carried out using 5\% DMRT. The addition of maltodextrin and egg white had significant effect on the characteristics of mushroom broth powder. The best product is obtained in the treatment of addition $10 \%$ maltodextrin and $20 \%$ of egg white concentration wich had characteristics such as color $L^{*}, a^{*}, b^{*}$ were $76.9 ; 9.35 ; 18.44$, foam density $0.20 \mathrm{~g} / \mathrm{mL}$, yield $29.10 \%$, solubility $96.41 \%$, water and protein content $6.58 \%$ and $5.77 \%$.

Keywords: Egg white, Broth Powder, Foam mat drying, Maltodextrin, Mushroom

\section{PENDAHULUAN}

Jamur tiram merupakan komoditas pangan yang cukup dikenal dan sering dikonsumsi oleh masyarakat Indonesia. Angka produksi jamur di Indonesia pada tahun 2017, menurut BPS, sebesar 3.7 Juta $\mathrm{Kg}$, namun jenis produk hasil olahan jamur di Indonesia masih 
terbatas. Oleh karena itu, diversifikasi dan pengembangan teknologi olahan jamur tiram cukup diperlukan bagi petani dan pengusaha jamur tiram.

Bubuk kaldu jamur merupakan salah satu produk olahan jamur. Umumnya bubuk kaldu diperoleh dari hasil pengeringan dari ekstrak bahan pangan seperti daging sapi, daging ayam dan seafood (Rizky dan Catur, 2018). Pembuatan bubuk kaldu jamur umumnya dilakukan dengan metode spray drying. Akan tetapi metode tersebut tergolong mahal dan pengoperasian alatnya sulit, sehingga sulit diaplikasikan pada industri menengah kebawah seperti UKM. Teknologi yang lebih sesuai untuk UKM adalah foam mat drying (pengeringan busa), sebab teknologinya sederhana dan biaya yang relatif lebih murah (Ratti \& Kudra, 2006).

Foam mat drying adalah metode pengeringan yang melibatkan pencampuran material yang akan dikeringkan dengan bahan pembusa untuk menghasilkan busa yang stabil dan dikeringkan dengan udara panas pada suhu yang berkisan atara $50-80^{\circ} \mathrm{C}$. Teknologi foam mat drying membutuhkan adanya bahan pembusa (foaming agent) dan bahan pengisi (filler) (Maria de Carvalho et al., 2017).

Bahan pembusa adalah suatu bahan aktif yang dapat menurunkan tegangan permukaan dan memfasilitasi pembentukan busa (Sharada, 2013). Penelitian menggunakan putih telur sebagai bahan pembusa dengan variasi konsentrasi penambahan sebesar $10 \%$, $15 \%$ dan $20 \%$. Penambahan putih telur akan memperbesar volume dari bubur, hal tersebut menyebabkan transfer panas semakin besar sehingga mempercepat proses pengeringan (Wahyu, 2016).

Menurut Estiasih dan Sofiah (2009), bahan pengisi akan berfungsi mempercepat proses pengeringan, meningkatkan padatan produk akhir serta sebagai pelindung bahan dari panas selama proses foam mat drying. Bahan pengisi yang digunakan adalah maltodekstrin dengan variasi konsentrasi penambahan 10\%, 15\% dan 20\%. Menurut Djaeni dkk (2016), maltodekstrin diduga dapat mempertahankan gelembung yang terbentuk dari putih telur, sehingga luas kontak sampel dengan media pengering dijaga tetap luas, sampai pengeringan selesai.

Tujuan penelitian ini untuk mengetahui pengaruh serta interaksi penambahan putih telur dan konsentrasi penambahan maltodekstrin terhadap karakteristik organoleptik, fisik, dan kimia bubuk kaldu jamur tiram putih yang dihasilkan menggunakan metode foam mat drying.

\section{BAHAN DAN METODE}

\section{Bahan}

Bahan-bahan yang digunakan dalam proses pembuatan bubuk kaldu jamur tiram putih yaitu jamur tiram putih, maltodekstrin, putih telur, bawang putih, daun bawang, seledri, garam dan gula. Bahan-bahan yang diperlukan untuk analisis kimia yaitu aquades, $\mathrm{CuSO}_{4} .5 \mathrm{H}_{2} \mathrm{O}$, NaKTartat, Larutan Protein BSA, NaOH.

\section{Alat}

Alat yang digunakan antara lain, baskom, timbangan analitik, mixer, blender, kompor, panci, sendok pengaduk, termometer, loyang, plastik kiloan, dan cabinet dryer, color reader, kompor listrik, desikator, timbangan analitik, vortex, oven, furnace, labu Kjeldahl, cawan, erlenmeyer, bulb, beaker glass, botol kaca, alumunium foil, pipet ukur, tabung reaksi, pipet tetes, spektrofotometer dan sentrifuse.

\section{Desain Penelitian}

Penelitian ini menggunakan Rancangan Acak Kelompok (RAK) Faktorial dengan 2 faktor perlakuan yaitu konsentrasi putih telur sebesar 10\%, 15\%, dan $20 \%$ serta konsentrasi maltodekstrin sebesar $10 \%, 15 \%$ dan $20 \%$. Dari kedua perlakuan tersebut dikombinasikan sehingga didapatkan 9 kombinasi perlakuan. Setiap perlakuan diulang 3 kali sehingga didapatkan 27 satuan percobaan (Tabel 1). 
Tabel 1. Rancangan penelitian menggunakan RAK faktorial

\begin{tabular}{cccc}
\hline Perlakuan & T1 (10\%) & T2 (15\%) & T3 (20\%) \\
\hline M1 (10\%) & M1T1 & M1T2 & M1T3 \\
M2 (15\%) & M2T1 & M2T2 & M2T3 \\
M3 (20\%) & M3T1 & M3T2 & M3T3 \\
\hline
\end{tabular}

Keterangan :

$\mathrm{M}$ : Konsentrasi Maltodekstrin

T : Konsentrasi Putih Telur

\section{Metode Penelitian}

Penelitian dilaksanakan dengan membuat kaldu jamur terlebih dahulu. Pertama jamur tiram putih dicuci hingga bersih dan ditiriskan, lalu jamur tiram putih diperkecil ukurannya dengan dihaluskan menggunakan blender kecepatan tertinggi selama 1 menit. Slurry jamur tiram direbus dengan air (perbandingan air: jamur $=2: 1$ ) selama 30 menit pada suhu $80^{\circ} \mathrm{C}$. Lalu ke dalam rebusan kaldu ditambahkan potongan bawang putih, daun bawang, seledri, garam, gula kemudian dipanaskan kembali selama 2 menit pada suhu $80^{\circ} \mathrm{C}$. Selanjutnya, air kaldu hasil rebusan disaring menggunakan kain saring, dibuang ampasnya dan didapatkan air kaldu jamur tiram putih. Kemudian masuk ke tahap pengeringan. Diambil $100 \mathrm{~mL}$ air kaldu dan kemudian ditambahkan maltodekstrin sebanyak $10 \%, 15 \%, 20 \%$ (b/v). Dilakukan pemanasan untuk membantu maltodekstrin larut. Setelah maltodekstrin larut, kaldu didinginkan terlebih dahulu hingga mencapai suhu ruang, kemudian ditambahkan putih telur sebanyak 10\%, 15\%, 20\% (b/v) dan dilakukan pengocokan dengan mixer selama 10 menit (kecepatan tinggi) hingga terbentuk busa kaldu. Busa kaldu yang terbentuk diletakkan diatas loyang dengan ketebalan $0.5 \mathrm{~cm}$ dan kemudian dikeringkan pada pengering kabinet selama 4 jam pada suhu $60^{\circ} \mathrm{C}$. Kaldu yang sudah kering di blender hingga halus dan didapatkan bubuk kaldu jamur tiram putih (Modifikasi Kamsiati, 2006).

\section{Analisis Data}

Data hasil pengamatan dianalisis menggunakan ANOVA, jika terdapat interaksi atau pengaruh nyata pada kedua perlakuan maka dilakukan uji lanjut DMRT 5\%. Pemilihan perlakuan terbaik pada penilitian ini dilakukan dengan menggunakan metode indeks efektifitas (de Garmo, 1984).

\section{Prosedur Analisis}

Analisis fisik meliputi Warna (color reader) (Yuwono dan Susanto, 1998), Densitas Busa (Ismaila et al, 2016), Rendemen, Daya larut (Yuwono dan Susanto, 1998). Analisis Kimia meliputi Kadar air metode oven (Sudarmadji dkk, 1998) dan kadar protein Metode Biuret (Apriyantono et al, 1989). Analisis organoleptik hedonic scale dengan parameter meliputi analisis rasa, warna, kenampakan, aroma. Pemilihan perlakuan terbaik (de Garmo, 1964).

\section{HASIL DAN PEMBAHASAN}

\section{Karakteristik Kaldu Jamur}

Kaldu jamur hasil ekstraksi dilakukan analisis terhadap parameter kadar protein dan warna. Hasil pengujian dapat dilihat pada Tabel 2.

Tabel 2. Karakteristik Kaldu Jamur

\begin{tabular}{cc}
\hline Karakteristik & Hasil Analisis \\
\hline Kadar Protein & $1.39 \mathrm{mg} / \mathrm{mL}$ \\
Warna $\left({ }^{*} \mathrm{~L} ;{ }^{*} \mathrm{a}\right.$; $\left.{ }^{*} \mathrm{~b}\right)$ & $28.84 ;-1.56 ; 3.48$ \\
\hline
\end{tabular}


Tabel 2 menunjukkan hasil analisis protein dan warna dari kaldu jamur. Jamur tiram segar mengandung $3.15 \%$ protein, $0.63 \%$ karbohidrat dan $0.10 \%$ lemak (Widyastuti, 2004). Dari hasil penelitian menujukkan penurunan kadar protein dari jamur tiram segar jika dibandingkan dengan kaldunya.

\section{Karakteristik Fisik dan Kimia Bubuk Kaldu Jamur}

Karakteristik fisik dan kimia bubuk kaldu jamur tiram putih dapat dilihat pada Tabel 3 dan Tabel 4

Tabel 3. Rerata Karakteristik Fisik dan Kimia Bubuk Kaldu Akibat Perlakuan Konsentrasi Maltodekstrin

\begin{tabular}{ccccccccc}
\hline $\begin{array}{c}\text { Perlakuan } \\
\text { (Konsentrasi } \\
\text { Maltodekstrin) }\end{array}$ & $\begin{array}{c}\text { Kadar } \\
\text { Air (\%) }\end{array}$ & $\begin{array}{c}\text { Kadar } \\
\text { Protein } \\
(\%)\end{array}$ & $\begin{array}{c}\text { Densitas } \\
(\mathbf{g} / \mathbf{m L})\end{array}$ & $\begin{array}{c}\text { Rendemen } \\
(\%)\end{array}$ & $\begin{array}{c}\text { Daya } \\
\text { Larut } \\
(\%)\end{array}$ & Nilai L* $^{*}$ & Nilai a* $^{*}$ & Nilai b* $^{*}$ \\
\hline $10 \%$ & $6.77 \pm$ & $4.88 \pm$ & $0.21 \pm$ & $27.34 \pm$ & $96.03 \pm$ & $76.81 \pm$ & $8.80 \pm$ & $18.78 \pm$ \\
& $0.20^{\mathrm{a}}$ & $0.55^{\mathrm{a}}$ & $0.02^{\mathrm{c}}$ & $1.43^{\mathrm{c}}$ & $0.37^{\mathrm{c}}$ & $0.57^{\mathrm{c}}$ & $0.47^{\mathrm{b}}$ & $0.37^{\mathrm{a}}$ \\
$15 \%$ & $6.50 \pm$ & $4.12 \pm$ & $0.25 \pm$ & $35.61 \pm$ & $97.34 \pm$ & $77.87 \pm$ & $9.94 \pm$ & $14.77 \pm$ \\
& $0.21^{\mathrm{b}}$ & $0.52^{\mathrm{b}}$ & $0.03^{\mathrm{b}}$ & $2.03^{\mathrm{b}}$ & $0.54^{\mathrm{b}}$ & $0.17^{\mathrm{b}}$ & $0.15^{\mathrm{a}}$ & $0.96^{\mathrm{b}}$ \\
$20 \%$ & $6.07 \pm$ & $3.36 \pm$ & $0.28 \pm$ & $44.68 \pm$ & $98.25 \pm$ & $80.24 \pm$ & $10.04 \pm$ & $14.45 \pm$ \\
& $0.25^{\mathrm{c}}$ & $0.53^{\mathrm{c}}$ & $0,03^{\mathrm{a}}$ & $1.99^{\mathrm{a}}$ & $0.50^{\mathrm{a}}$ & $0.56^{\mathrm{a}}$ & $1.03^{\mathrm{a}}$ & $0.36^{\mathrm{b}}$ \\
\hline
\end{tabular}

Keterangan : 1) Setiap data hasil analisis merupakan 3 ulangan \pm standar deviasi

2) Angka yang didampingi notasi berbeda menunjukkan perbedaan nyata $(p<0,05)$

Tabel 3 menunjukkan bahwa perbedaan konsentrasi maltodekstrin berpengaruh nyata pada karakteristik kadar air, kadar protein, densitas busa, rendemen, daya larut, nilai $L^{*}, a^{*}$ dan $b^{*}$. Pada parameter kadar air, nilainya semakin menurun seiring penambahan maltodekstrin, karena peningkatan maltodekstrin yang ditambahkan akan menaikkan total padatan dan menurunkan kadar air pada sampel, sehingga kadar air awal bahan sebelum pengeringan yang berbeda membuat produk dengan kadar air yang lebih kecil akan lebih cepat kering dan kadar airnya menjadi lebih rendah (Hayati dkk, 2015).

Kadar protein bubuk kaldu turun seiring peningkatan konsentrasi maltodekstrin. Peningkatan konsentrasi maltodekstrin yang ditambahkan mengakibatkan bobot akhir/ rendemen produk meningkat. Penambahan padatan dari maltodekstrin yang tidak mengandung protein akan mengurangi kadar protein dari produk akhir (Nurzarrah dkk, 2017).

Densitas dari busa kaldu meningkat seiring panambahan konsentrasi maltodekstrin. Menurut Widyasanti dkk (2018), peningkatan ini dikarenakan penambahan maltodekstrin akan meningkatkan berat mula-mula dari sampel sebelum pembentukan foam. oleh karena itu densitas foam akan meningkat karena peningkatan berat sampel

Pada parameter rendemen, rendemen bubuk kaldu jamur meningkat diikuti dengan penambahan konsentrasi maltodekstin, dikarenakan maltodekstrin yang ditambahkan akan meningkatkan padatan dari sampel yang ketika dikeringkan, padatan tersebut tidak hilang dan akan menambah bobot akhir dari produk sehingga rendemen meningkat (Hayati dkk, 2015).

Daya larut bubuk kaldu jamur meningkat seiring panambahan maltodekstrin. Maltodekstrin memiliki sifat pengikat air dengan cepat, sehingga semakin besar konsentrasi maltodekstrin yang ditambahkan, gugus hidroksilnya juga akan bertambah mengakibatkan tingkat pengikatan airnya cepat (Triani dkk, 2015).

Nilai $L^{*}$ dari bubuk kaldu menunjukkan nilai yang lebih dari 50 , tinggi nya nilai $L^{*}$ tersebut menunjukkan bahwa semua perlakuan secara keseluruhan menghasilkan bubuk dengan warna yang terang/cerah. Penambahan konsentrasi maltodekstrin tinggi meningkatkan perlindungan warna bubuk sehingga warna dapat dipertahankan (Paramita, 2015).

Pada parameter warna nilai $a^{*}$, penambahan konsentrasi maltodekstrin membuat nilai $\mathrm{a}^{*}$ bubuk kaldu jamur yang didapat juga akan meningkat. Nilai $\mathrm{a}^{*}$ yang semakin meningkat 
dengan ditunjukan nilai positif yang semakin besar artinya produk cenderung semakin mendekati warna merah atau berkurang warna kehijauannya (Siska, 2015).

Pada parameter warna nilai $b^{*}$, penambahan konsentrasi maltodekstrin membuat nilai $b^{*}$ bubuk kaldu jamur yang didapat menurun. Artinya dengan penambahan maltodekstrin produk akan cenderung semakin mendekati warna biru dan dan berkurang warna kekuningannya (Nurzarrah dkk, 2017).

Tabel 4. Rerata Karakteristik Fisik dan Kimia Bubuk Kaldu Akibat Perlakuan Konsentrasi Putih Telur

\begin{tabular}{ccccccccc}
\hline $\begin{array}{c}\text { Perlakuan } \\
\text { (Konsentrasi } \\
\text { Putih Telur) }\end{array}$ & $\begin{array}{c}\text { Kadar } \\
\text { Air }(\%)\end{array}$ & $\begin{array}{c}\text { Kadar } \\
\text { Protein } \\
(\%)\end{array}$ & $\begin{array}{c}\text { Densitas } \\
(\mathbf{g} / \mathbf{m L})\end{array}$ & $\begin{array}{c}\text { Rendemen } \\
(\%)\end{array}$ & $\begin{array}{c}\text { Daya } \\
\text { Larut } \\
(\%)\end{array}$ & Nilai $\mathbf{L}^{*}$ & Nilai $\mathbf{a}^{*}$ & Nilai $^{*}$ \\
\hline $10 \%$ & $6.67 \pm$ & $3.58 \pm$ & $0.27 \pm$ & $33.93 \pm$ & $96.73 \pm$ & $78.39 \pm$ & $9.10 \pm$ & $15.54 \pm$ \\
& $0.32^{\mathrm{a}}$ & $0.32^{\mathrm{c}}$ & $0,04^{\mathrm{a}}$ & $8,98^{\mathrm{c}}$ & $1.17^{\mathrm{c}}$ & 1.29 & $0.69^{\mathrm{b}}$ & 2.76 \\
$15 \%$ & $6.44 \pm$ & $4.13 \pm$ & $0.25 \pm$ & $36.17 \pm$ & $97.21 \pm$ & $78.06 \pm$ & $9.52 \pm$ & $16.15 \pm$ \\
& $0.36^{\mathrm{b}}$ & $0.36^{\mathrm{b}}$ & $0,03^{\mathrm{b}}$ & $8,64^{\mathrm{b}}$ & $1.15^{\mathrm{b}}$ & 1.91 & $0.82^{\mathrm{b}}$ & 2.61 \\
$20 \%$ & $6.28 \pm$ & $4.64 \pm$ & $0.22 \pm$ & $37.53 \pm$ & $97.67 \pm$ & $78.49 \pm$ & $10.16 \pm$ & $16.31 \pm$ \\
& $0.38^{\mathrm{c}}$ & $0.38^{\mathrm{a}}$ & $0,03^{\mathrm{c}}$ & $8,42^{\mathrm{a}}$ & $1,03^{\mathrm{a}}$ & 2.11 & $0.85^{\mathrm{a}}$ & 1.92 \\
\hline
\end{tabular}

Keterangan : 1) Setiap data hasil analisis merupakan 3 ulangan \pm standar deviasi

2) Angka yang didampingi notasi berbeda menunjukkan perbedaan nyata $(p<0,05)$

Tabel 4 menunjukkan perbedaan konsentrasi putih telur berpengaruh nyata terhadap karakteristik kadar air, kadar protein, densitas busa, rendemen, daya larut dan nilai $a^{*}$. Pada parameter kadar air, nilainya semakin menurun seiring penambahan putih telur, putih telur yang ditambahkan pada sampel memiliki daya pengembangan yang membantu proses perubahan sampel dari bentuk cair menjadi bentuk busa (Soekarto, 2013). Busa yang telah terbentuk memiliki struktur berongga sehingga memperbesar volume dan luas permukaan sampel (Kudra dan Ratti, 2006). Luas permukaan sampel yang besar akan membuat kontak udara panas dengan sampel semakin tinggi yang berakibat pada laju pengeringan yang lebih besar.

Kadar protein bubuk kaldu meningkat seiring peningkatan konsentrasi putih telur. Peningkatan ini terjadi dikarenakan putih telur tinggi akan protein, yaitu sebesar $10.9 \%$ (Sudaryani, 2008). Protein pada putih telur yang ditambahkan tidak akan hilang selama proses pengeringan, sehingga akan meningkatkan kadar protein dari bubuk kaldu.

Densitas dari foam kaldu meningkat seiring panambahan konsentrasi putih telur. Penambahan konsentrasi putih telur yang lebih besar meningkatkan pembentukan busa yang dapat memperbesar volume foam sehingga nilai densitas busa lebih rendah dibanding nilai densitas busa dari perlakuan yang sama dengan konsentrasi putih telur yang lebih rendah (Kudra dan Ratti, 2006).

Untuk parameter rendemen terjadi peningkatan seiring dengan penambahan putih telur. Penambahan konsentrasi putih telur akan meingkatkan rendemen dari produk akhir dikarenakan pada putih telur mengandung air yang cukup tinggi sebesar $86.7 \%$. Padatan dari putih telur yang ditambahkan tidak akan menghilang selama proses pengeringan dan akan menambah bobot rendemen (Kamsiati, 2006).

Daya larut bubuk kaldu jamur meningkat seiring panambahan putih telur. Peningkatan daya larut disebabkan karena peningkatan konsentrasi putih telur akan menaikkan kadar air produk akhir. Peningkatan kandungan air dalam bahan dapat menyebabkan terbentuknya gumpalan, sehingga waktu pemecahan ikatan antar partikel juga semakin meningkat, sehingga kelarutan produk juga menurun (Widyasanti dkk, 2018).

Pada nilai $L^{*}$ dan $b^{*}$ dari bubuk kaldu tidak terjadi perbedaan nilai yang signifikan akibat penambahan putih telur antar perlakuan. Penambahan putih telur tidak memberikan pengaruh nyata dikarenakan komposisi putih telur sendiri yang didominasi oleh air sebesar 87\% (Winarti, 2004). Kandungan air yang tinggi dan padatan yang rendah membuat penambahan telur tidak memberikan pengaruh terhadap perubahan kecerahan dan nlai $b^{*}$ produk akhir. 
Pada parameter warna nilai $a^{*}$, penambahan putih telur meningkatkan nilai $a^{*}$ dari produk bubuk kaldu jamur. Bahan pangan dalam bentuk cair yang ditambah dengan putih telur akan cepat mengering. Putih telur yang dibusakan mampu melindungi bahan tersebut dari reaksi Maillard. Akibatnya derajat kemerahan bubuk instant dapat dipertahankan karena buih putih telur yang tidak tembus pandang menutupi warna bahan tersebut (Karim dan Wai, 1999).

\section{Karakteristik Organoleptik Bubuk Kaldu Jamur}

Pengujian organoleptik bubuk kaldu jamur dilakukan dengan melarutkan kembali bubuk kaldu pada air hangat dengan perbandingan $10 \mathrm{~g}$ dalam $600 \mathrm{~mL}$ air. Uji organoleptik dilakukan menggunakan metode Hedonic Scale Scoring yang mempunyai skala hedonik 1 hingga 7 (sangat tidak suka hingga sangat suka). Uji dilakukan kepada 42 panelis tidak terlatih. Rerata tingkat kesukaan panelis terhadap atribut organoleptik produk dapat dilihat pada Tabel 5.

Tabel 5. Rerata Tingkat Kesukaan Atribut Organoleptik Bubuk Kaldu Jamur Tiram Putih

\begin{tabular}{cccccccccc}
\hline \multirow{2}{*}{ Atribut } & \multicolumn{8}{c}{ Perlakuan } \\
\cline { 2 - 10 } & M1T1 & M1T2 & M1T3 & M2T1 & M2T2 & M2T3 & M3T1 & M3T2 & M3T1 \\
\hline \multirow{2}{*}{ Warna } & $4.62 \pm$ & $4.60 \pm$ & $4.79 \pm$ & $4.76 \pm$ & $4.55 \pm$ & $4.60 \pm$ & $4.60 \pm$ & $4.86 \pm$ & $4.69 \pm$ \\
& 1.08 & 1.13 & 1.12 & 1.25 & 1.21 & 1.34 & 1.19 & 1.26 & 0.92 \\
Aroma & $4.45 \pm$ & $4.55 \pm$ & $4.71 \pm$ & $4.50 \pm$ & $3.88 \pm$ & $4.88 \pm$ & $3.69 \pm$ & $4.24 \pm$ & $3.64 \pm$ \\
& $1.37^{\text {cd }}$ & $1.33^{\text {cd }}$ & $1.40^{\mathrm{d}}$ & $1.40^{\text {cd }}$ & $1.37^{\mathrm{ab}}$ & $1.25^{\mathrm{d}}$ & $1.39^{\mathrm{ab}}$ & $1.16^{\mathrm{bc}}$ & $1.27^{\mathrm{a}}$ \\
Penampakan & $4.24 \pm$ & $4.31 \pm$ & $4.81 \pm$ & $4.69 \pm$ & $4.55 \pm$ & $4.26 \pm$ & $4.38 \pm$ & $4.60 \pm$ & $4.81 \pm$ \\
& $1.23^{\mathrm{a}}$ & $1.30^{\mathrm{a}}$ & $1.19^{\mathrm{b}}$ & $1.18^{\mathrm{b}}$ & $1.02^{\mathrm{ab}}$ & $1.27^{\mathrm{a}}$ & $1.13^{\mathrm{ab}}$ & $1.19^{\mathrm{ab}}$ & $1.11^{\mathrm{b}}$ \\
Rasa & $5.24 \pm$ & $5.64 \pm$ & $5.05 \pm$ & $4.74 \pm$ & $3.95 \pm$ & $4.40 \pm$ & $3.95 \pm$ & $4.00 \pm$ & $3.60 \pm$ \\
& $1.25^{\mathrm{de}}$ & $1.03^{\mathrm{e}}$ & $1.15^{\mathrm{d}}$ & $1.34^{\mathrm{cd}}$ & $1.34^{\mathrm{a}}$ & $1.56^{\mathrm{bc}}$ & $1.38^{\mathrm{a}}$ & $1.23^{\mathrm{ab}}$ & $1.06^{\mathrm{a}}$ \\
\hline
\end{tabular}

Keterangan : 1) Setiap data hasil analisis merupakan 3 ulangan \pm standar deviasi

2) Angka yang didampingi notasi berbeda menunjukkan perbedaan nyata $(p<0,05)$

Tabel 5 menunjukkan bahwa kombinasi perlakuan konsentrasi maltodekstrin dan konsentrasi putih telur memberikan pengaruh yang nyata terhadap karakteristik organoleptik bubuk kaldu jamur pada parameter aroma, penampakan dan rasa. Pada atribut warna, tidak memberikan pengaruh nyata.

Berdasarkan data hasil analisis karakteristik fisik produk, kombinasi perlakuan maltodekstrin yang rendah menghasilkan bubuk yang memiliki tingkat kecerahan yang lebih rendah di bandingkan dengan produk dengan konsentrasi perlakuan yang lebih tinggi. Namun ketika bubuk dilarukan kembali pada air hangat menghasilkan kaldu dengan warna yang tidak jauh berbeda antar setiap kombinasi perlakuan. Kaldu yang dihasilkan memiliki warna putih pucat.

Pada penilaian atribut aroma, rerata penilaian tidak memiliki perbedaan yang cukup jauh. Penggunaan konsentrasi maltodekstrin yang rendah cenderung mempunyai aroma yang lebih disukai. Hal tersebut diduga karena pada konsentrasi maltodekstrin yang rendah memiliki flavor jamur yang lebih pekat, sehingga aroma kaldu lebih dapat terdeteksi oleh indra penciuman. Menurut penelitian Mulyadi dkk (2013), tingginya konsentrasi bahan pengisi akan dapat menurunkan cita rasa bahan utama. Meilgaard et al. (2000), menyebutkan bahwa terbentuknya senyawa volatil akan menimbulkan aroma pada makanan dan setiap makanan mempunya aroma yang berbeda. Perbedaan cara memasak akan menghasilkan aroma makanan yang berbeda.

Pada atribut kenampakan kaldu jamur, penilaian panelis cenderung lebih tinggi seiring bertambahnya konsentrasi maltodekstrin. Jika dibandingkan dengan data hasil pengukuran kelarutan dari produk. Semakin tinggi maltodekstrin maka produk akan lebih mudah larut sehingga kaldu yang dihasilkan memiliki kenampakan lebih bening/tidak keruh. Begitu pula pada faktor penambahan putih telur. Semakin tinggi konsentrasi putih telur yang ditambahkan 
penilaian panelis teradap atribut kenampakan juga semakin suka. Hal tersebut juga berhubungan dengan kelarutan produk yang semakin tinggi seiring dengan penambahan kosentrasi putih telur.

Pada atribut rasa kaldu jamur, perlakuan dengan penambahan maltodekstrin yang rendah mempunyai hasil penilaian yang lebih besar dibandingkan dengan perlakuan konsentrasi maltodekstrin yang tinggi. Jika dihubungkan dengan kadar protein dari produk, kedua perlakuan tersebut juga memiliki kandungan protein yang tinggi dibanding perlakuan yang lainnya. Diduga kandungan protein yang tinggi tersebut berbanding lurus dengan kandungan asam amino glutamat yang tinggi sehingga dapat memberikan rasa disukai panelis karena rasa yang lebih gurih (Winarno, 2004).

\section{Karakteristik Perlakuan Terbaik}

Penentuan perlakuan terbaik diperoleh dengan metode indeks efektifitas berdasarkan karakteristik organoleptik dari produk yang dihasilkan. didapatkan hasil perlakuan terbaik yakni pada perlakuan dengan penambahan konsentrasi maltodekstrin $10 \%$ dan konsentrasi putih telur $20 \%$. Perlakuan tersebut memiliki karakteristik fisik, kimia serta organoleptik seperti pada Tabel 6.

Tabel 6. Karakteristik Fisik, Kimia dan Organoleptik pada Perlakuan Terbaik

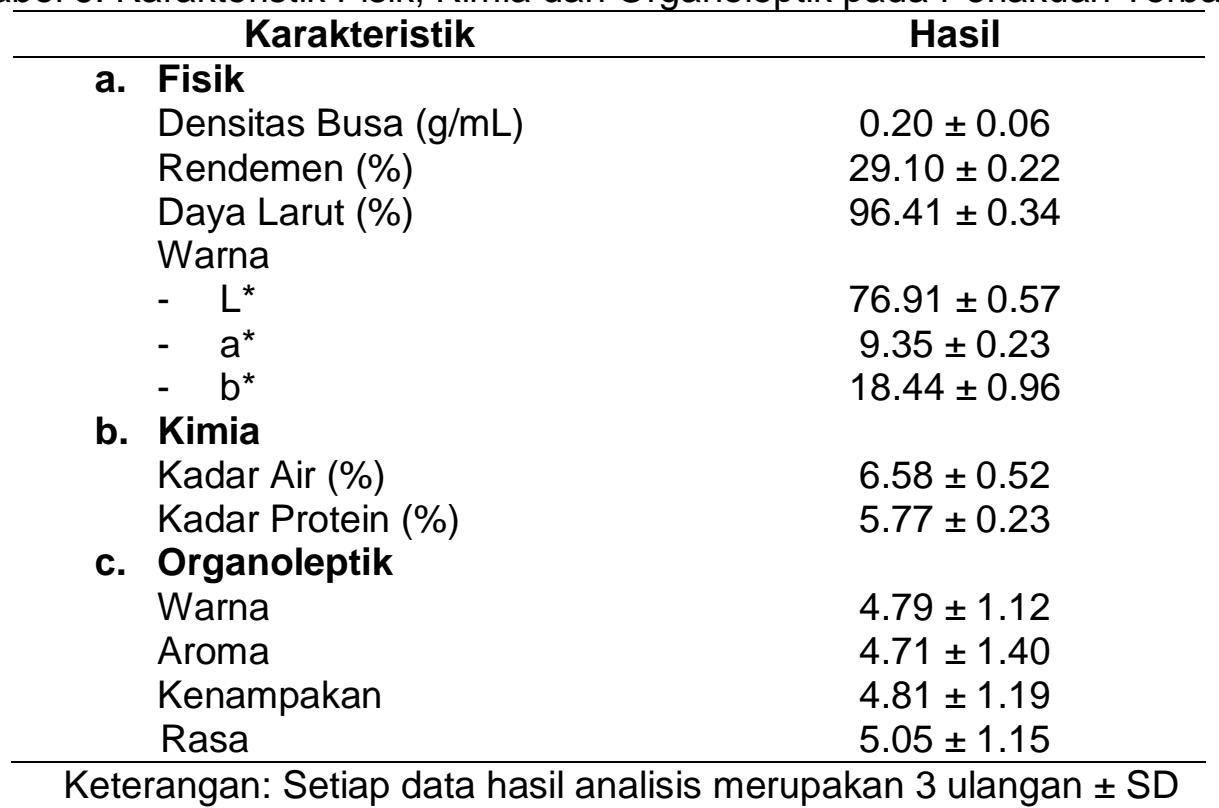

\section{SIMPULAN}

Tidak terdapat interaksi antara konsentrasi maltodekstrin dan konsentrasi putih telur terhadap karakteristik fisikokimia dan organoleptik dari bubuk kaldu jamur yang dihasilkan. Penambahan berbagai konsentrasi maltodekstrin berpengaruh nyata pada kadar air, kadar protein, daya larut, densitas, rendemen, nilai $L^{*}, a^{*}$ dan $b^{*}$, serta atribut organoleptik aroma, kenampakan dan rasa. Penambahan konsentrasi putih telur yang berbeda berpengaruh nyata pada kadar air, protein, daya larut, densitas, rendemen dan nilai $b^{*}$, serta atribut organoleptik aroma, kenampakan dan rasa. Berdasarkan hasil uji organoleptik, perlakuan terbaik adalah perlakuan penambahan maltodekstrin sebesar $10 \%$ dan putih telur $20 \%$. Hasil perlakuan terbaik memiliki karakteristik warna $L^{*}, a^{*}, b^{*}$ sebesar $76.9 ; 9.35 ; 18.44$, Densitas busa sebesar $0.20 \mathrm{~g} / \mathrm{mL}$, rendemen $29.10 \%$, daya larut $96.41 \%$, kadar air sebesar $6.58 \%$, kadar protein sebesar $5.77 \%$. 


\section{DAFTAR PUSTAKA}

Apriyantono, A., Fardiaz, D., Puspitasari, N.L., Sedamawati, Y., dan Budianto, S. 1989. Petunjuk Laboratorium Analisis Pangan. Pusat Antar Universitas Pangan dan Gizi. Institut Pertanian Bogor. Bogor

Djaeni, M., Triyastuti M.S., dan Rahardjo H.S. 2016. Pengaruh pengeringan dengan metode gelembung terhadap sifat fisik produk ekstrak bunga rosela. Reaktor 16(2): 96-102.

Estiasih, T dan Sofiah, E. 2009. Stabilitas Antioksidan Bubuk Keluak (Penguim edule reinw) Selama Pengeringan dan Pemasakan. Jurnal Teknologi Pertanian 10(2): 115-112

Hayati, R., Dewi, A., Nugrahani, R., dan Satibi, L. 2015. Pengaruh Konsentrasi Maltodekstrin Terhadap Kadar Air dan Waktu Melarutnya Santan Kelapa Bubuk (Coconut Milk Powder) Dalam Air. Jurnal Teknologi Universitas Muhammadiyah Jakarta Vol.7 (No 1): Hal 56-59

Ismalia, A.R., Sogunle, K,A., dan Adebayo, Q. 2016. Foam density characteristics of sweet potato paste using gliserol monostearat and egg albumin as foaming agents. European Journal of Food Science and Technology 4(1): 1-9.

Kamsiati, E. 2006. Pembuatan Bubuk Sari Buah Tomat (Licopersicon Esculentummill.) dengan Metode "Foam-Mat Drying". Jurnal Teknologi Pertanian, Vol. 7 No. 2. p113119

Karim, A. A. dan Wai, C. C. 1999. Foam mat drying starfruit ( Averrhoa carambola L.) puree. Stability and air drying characteristics. $J$ food Chemistry. 64. p337-343.

Kudra, T. dan Ratti, C. 2006. Foam-mat drying: Energy and cost analyses. Biosystem Engineering 48: 327-332.

Laila, D. 2010. Perbandingan Metode Maserasi, Remaserasi, Perkolasi dan Reperkolasi Terhadap Rendemen Ekstrak Temulawak. Skripsi. Institut Pertanian Bogor. Bogor

Maria de Carvalho, T. I. M., Nogueira, T. Y .K., Mauro, M. A., Gomez-Alonzo S., Gomez E., da Sila R., Hermosin, G. I dan Lago-Vanzela, E. S. 2017. Dehydration of Jambolan Juice During Foam Mat Drying: Quantitative and Qualitative Changes of the Phenolic Compound. Food Research International. 102

Meilgaard, M., Civille, G.V., Carr, B.T. 2000. Sensory Evaluation Techniques. Boca Raton. Florida: CRC Press

Mulyadi, A. F, Maligan, J. M, Wignyanto dan Hermansyah, R. 2013. Organoleptic Characteristics of Natural Flavour Powder From Waste of Swimming Blue Crabs (Portunus pelagicus) Processing: Study on Dextrin Concentration and Drying Temperature. Jurnal Teknologi Pertanian Vol. 14 No. 3 [Desember 2013] 183-192

Nurzarrah, T., Fidela, V., Mimi, H dan Khandra, F. 2017. Pengaruh perbedaan jenis dan konsentrasi bahan pengisi terhadap karakteristik pewarna buah senduduk. Jurnal Teknologi Pertanian Andalas Vol. 21, No.2

Paramita, I., Mulyani, S., dan Hartiati, A. 2015. Pengaruh Konsentrasi Maltodekstrin Dan Suhu Pengeringan Terhadap Karakteristik Bubuk Minuman Sinom. Jurnal Rekayasa dan Manajemen Agroindustri: P58-68

Ratti, C. dan Kudra T. 2006. Drying of foamed biological material: oportunities and challenges. Journal Drying Technology 24(9): 1101-1108

Rizky, A.M. dan Catur, A. 2018. Kaldu Ayam Instan dengan Substitusi Tepung Hati Ayam sebagai Alternatif Bumbu untuk Mencegah Anemia. Journal Amerta Nutrition 2(1). 7482

Sharada S. 2013. Studies on effect of various operating parameters and foaming agent drying of fruit and vegetables. International Journal of Modern Engineering Research (IJMER). 3(3): 1512-1519

Siska, Y T,.., Wahono, H, S. 2014. Pengaruh Lama Pengeringan Dan Konsentrasi Maltodekstrin Terhadap Karakteristik Fisik Kimia Dan Organoleptik Minuman Instan Daun Mengkudu (Morinda citrifolia L). Jurnal Pangan dan Agroindustri. Vol.3 (No 1) : Hal.41-52

Soekarto, S. T.(2013). Teknologi Penanganan dan Pengolahan Telur. Alfabeta: Bogor 
Sudarmadji, S., B. Haryono dan Suhardi. 1989. Analisis Bahan Baku Makanan dan Pertanian. Penerbit Liberty. Yogyakarta

Sudaryani, T. 2008. Kualitas Telur. Jakarta: Penebar Swadaya

Triani, L., Ismed, S dan Sentosa, G. 2015. Pengaruh suhu pengeringan dan konsentrasi dekstrin terhadap mutu minuman instan bit merah. Jurnal Rekayasa pangan dan Pertanian. Vol 3 No.2

Wahyu ,T. 2016. Karakteristik Mutu Tepung Labu Kuning (Cucurbita Moschata) Hasil Pengeringan Metode Foam-Mat Drying Menggunakan Oven Microwave. Skripsi. Universitas Jember. Jember

Widyasanti, A., Nur, A dan Safirah, N. 2018. Pengaruh Penambahan Maltodekstrin terhadap fisikokimia bubuk tomat hasil pengeringan pembusaan. Jurnal Agroindustri. Vol 22, No1

Widyastuti, N. 2004. Optimasi Proses Pengeringan Tepung Jamur Tiram Putih (Pleurotus ostreanus). Jurnal IImu Kefarmasian (2)1: 1- 4

Winarno, F.G. 2004. Kimia Pangan dan Gizi. Gramedia, Jakarta

Winarno. F.G. dan Koswara. 2002. Telur: Komposisi Penanganan dan Pengolahannya. MBrio Press. Bogor

Winarti, E. 2004. Peluang Telur Infertil pada Usaha Penetasan Telur Itik sebagai Telur Konsumsi. Makalah Seminar Nasional Teknologi. 768-771

Yuwono, S.S., dan Susanto, T. 1998. Pengujian Fisik Pangan. Universitas Brawijaya. Malang 